\title{
Association between low first trimester maternal serum PAPP-A levels and presence of unilateral or bilateral uterine artery diastolic notches
}

\author{
Fırat Tülek ${ }^{1,2}$ (D) , Ali Gemici ${ }^{3}$ (D) , Alper Kahraman ${ }^{4}$ (D) \\ ${ }^{1}$ Department of Obstetrics and Gynecology, Ataşebir Memorial Hospital, Istanbul, Turkey \\ ${ }^{2}$ Faculty of Health Sciences, Üskiidar University, Istanbul, Turkey \\ ${ }^{3}$ Department of Obstetrics and Gynecology, Giiven Hospital, Ankara, Turkey \\ ${ }^{4}$ Department of Obstetrics and Gynecology, Haseki Training and Research Hospital, Health Sciences University, Istanbul, Turkey
}

\begin{abstract}
Objective: Uterine artery impedance is known to have an effect on first trimester aneuploidy screening biomarkers. In this study we aim to compare first trimester screening parameters in women with and without uterine artery diastolic notches.

Methods: This retrospective case control study was conducted in a single tertiary center by obtaining medical records of women that admitted for first trimester pregnancy follow-up. Singleton pregnancies without structural anomalies, chromosomal anomalies and obstetric complications were included in the study. 268 women with first trimester unilateral uterine artery diastolic notches are constituted study group 1, 149 women with bilateral uterine artery diastolic notches constituted study group 2. 200 women were randomly selected as control group.

Results: Significantly decreased PAPP-A levels were found in both study groups. PAPP-A levels were even lower in women with bilateral notches in comparison to unilateral notches. Fetal birth weights and gestational ages at birth were also found significantly lower in study groups. Beta human chorionic gonadotropin levels and nuchal translucency measurements were found similar. Prevalence of false positive first trimester aneuploidy screening test results were significantly higher in women with bilateral uterine artery diastolic notches.

Conclusion: Presence of first trimester uterine artery diastolic notches, particularly the presence of bilateral diastolic notches, is related with decreased PAPP-A levels in first trimester aneuploidy screening and lead to higher false positive rates in first trimester aneuploidy screening and consequently more unnecessary invasive procedures.
\end{abstract}

Keywords: Uterine artery, diastolic notch, free B-hCG, PAPP-A.
Özet: Düşük birinci trimester maternal serum PAPP-A seviyeleri ile ünilateral veya bilateral uterin arterde diyastolik çentik varlığı arasındaki ilişki

Amaç: Uterin arter empedansının birinci trimester anöploidi tarama biyo-belirteçleri üzerinde etkisi olduğu bilinmektedir. Bu çalışmada, uterin arterde diyastolik çentikleri olan ve olmayan kadınlarda birinci trimester tarama parametrelerini karşılaştırmayı amaçladık.

Yöntem: Bu retrospektif olgu kontrol çalışması, birinci trimester gebelik takibi için başvuran kadınların tıbbi kayıtlarına erişilerek tek bir üçüncü basamak merkezde gerçekleştirilmiştir. Çalışmaya, yapısal anomalisi, kromozom anomalisi ve obstetrik komplikasyonu olmayan tekil gebelikler dahil edilmiştir. Birinci trimester ünilateral uterin arter diyastolik çentiği olan 268 kadın 1. çalışma grubunu, bilateral uterin arter diyastolik çentiği olan 149 kadın ise 2 . çalışma grubunu oluşturmuştur. Rastgele seçilen 200 kadın kontrol grubunu oluşturmuştur.

Bulgular: Her iki çalışma grubunda da PAPP-A seviyelerinin anlamlı şekilde azaldığı bulundu. PAPP-A seviyeleri, ünilateral çentiklere kıyasla bilateral çentikli kadınlarda daha da düşüktü. Fetal doğum ağırlıkları ve doğumda gestasyonel yaş da çalışma gruplarında anlamlı şekilde düşüktü. Beta insan koryonik gonadotropin seviyeleri ve ense kalınlığı ölçümleri benzer bulundu. Yanlış pozitif birinci trimester anöploidi tarama testi sonuçlarının prevalansı, bilateral uterin arterde diyastolik çentikleri olan kadınlarda anlam11 şekilde daha yüksekti.

Sonuç: Birinci trimester uterin arter diyastolik çentik varlığı, özellikle de bilateral diyastolik çentik varlığı, birinci trimester anöploidi taramasında azalmış PAPP-A seviyeleri ile ilişkilidir ve birinci trimester anöploidi taramasında daha yüksek yanlış pozitif oranlara ve dolayısıyla daha fazla gereksiz invazif girişime yol açmaktadır.

Anahtar sözcükler: Uterin arter, diyastolik çentik, serbest B-hCG, PAPP-A.

Correspondence: Fırat Tülek, MD. Department of Obstetrics and Gynecology, Ataşehir Memorial Hospital, İstanbul, Turkey. e-mail: firattulek@yahoo.com / Received: March 14, 2021; Accepted: July 27, 2021

How to cite this article: Tülek F, Gemici A, Kahraman A. Association between low first trimester maternal serum PAPP-A levels and presence of unilateral or bilateral uterine artery diastolic notches. Perinatal Journal 2021;29(2):113-119. doi:10.2399/prn.21.0292006 


\section{Introduction}

Pregnancy-associated plasma protein A (PAPP-A), is first discovered in pregnant women's plasma so it was named accordingly in 1974. ${ }^{[1]}$ PAPP-A, also known as pappalysin-1, is secreted from syncytial trophoblasts. ${ }^{[2]}$ It takes place in regulation of insulin-like growth factor (IGF) homeostasis by serving in degradation of insulinlike growth hormone binding proteins (IGFBP), particularly the IGFBP-4 in plasma, resultantly increasing the available IGF in plasma and its mitogenic effects. ${ }^{[3,4]}$ It is also involved in angiogenesis, matrix mineralization and immunomodulation. ${ }^{[5]}$

PAPP-A is widely used as a serum biomarker in first trimester aneuploidy screening tests. Low maternal plasma PAPP-A levels also related with high aneuploidy risk, particularly with trisomy 21 . Besides this, PAPP-A is known to be reduced in various adverse obstetric complications such as preeclampsia, low birth weight, gestational hypertension, preterm delivery, stillbirth, preterm premature rupture of membranes and placental abruption. ${ }^{[6]}$ First trimester maternal plasma PAPP-A is also recommended as a second line screening tool for preeclampsia in combination with uterine artery pulsatility index (UTPI), in settings where placental growth factor measurements are unavailable..$^{[7]}$

Recently some studies indicate reduced PAPP-A levels in women with increased first trimester UTPI values. ${ }^{[8,9]}$ In this study we aimed to compare first trimester aneuploidy screening test biomarkers in women with or without first trimester uterine artery diastolic notch.

\section{Methods}

This retrospective case-control study was conducted on hospital records of women admitted to Obstetrics and Gynecology Department of Ataşehir Memorial Hospital in Istanbul, Turkey for first trimester pregnancy followup between May 2013 and 2020. The objective of this study is to compare first trimester aneuploidy screening test parameters in women with and without uterine artery diastolic notches. A total of 4528 women were found to admit to clinic for first trimester obstetrical care follow-ups that underwent first trimester aneuploidy screening within the selected period of time. As an adoption of routine obstetrical care in our institution, uterine artery Doppler studies are performed in all pregnant women between 11th and 14th gestational weeks besides first trimester aneuploidy screening tests including measurement of maternal serum markers, fetal NT thickness and fetal crown-rump length (CRL). Institutional review board approval was obtained for this study (IRB No: 61351342/2020-326 Date: 30/06/2020) and women included in the study provided informed consents. Exclusion criteria were cases with aneuploid fetuses or structural anomalies, multiple pregnancies and pregnancies complicated with preeclampsia, gestational hypertension and placental abruption. Preeclampsia and gestational hypertension were diagnosed in accordance with descriptions of ACOG. ${ }^{[10]}$ Women that missed follow-up visits or delivered in another institution were also excluded from the study. Within rest of the objects, 417 women were found to have uterine artery diastolic notches. 268 of those 417 women had unilateral uterine artery diastolic notch and constituted the study group 1 . 149 of them had bilateral uterine artery notch and constituted the study group 2. A power analysis was conducted by using $G^{*}$ Power version 3.1.9.2 (Heinrich Heine University, Düsseldorf, Germany) and minimum number of controls were calculated as 198 with a 0.95 power and 0.25 effect size. Randomly selected 200 women without uterine artery diastolic notch included in control group.

Gestational age was calculated from the last menstrual period, confirmed by CRL measurement. Whenever the discrepancies between gestational ages calculated based on last menstrual date and calculated depending on CRL measurements are more than 7 days, gestational age was corrected accordingly with CRL measurement. First trimester screening tests were performed between 11th and 14th weeks of gestation. On the day of ultrasound, serum samples were also taken. Collected plasma samples have been analyzed within period of 3 hours. Roche Cobas e 601 module (Roche Diagnostics, Basel, Switzerland) for immunoassay tests, free human chorionic gonadotropin (B-hCG) and PAPP-A kits were used to analyze plasma samples. MoM values were also used to express the levels of maternal serum markers. $\mathrm{MoM}$ values were adjusted for gestational age, maternal body weight, smoking status and the route of conception.

Doppler ultrasound examinations for uterine artery were performed as described by O'Gorman et al. ${ }^{[1]}$ Transabdominal ultrasound probe was placed lateral part of the isthmic part of the uterus and moved laterally until 
the paracervical vascular plexus was seen. Color Doppler was turned on, and the uterine artery was identified as it turned cranially to make its ascent to the uterine body. Measurements were taken at this point, before the uterine artery branched into the arcuate arteries. Once it was ensured that the angle was less than 60 degrees, the pulsed Doppler gate was placed over the vessel. Angle correction was then applied, and the signal updated until at least four consecutive flow velocity waveforms of good quality were obtained. The resistance index (RI) and pulsatility index (PI) were measured and recorded bilaterally, as well as the presence or absence of an early diastolic notch. Diastolic notch was defined as slower velocity after systolic flow but before diastolic flow.

High risk first trimester aneuploidy screening test cut off was considered $1 / 270$ for trisomy 21 . False positivity was defined as patients with a trisomy 21 risk $>1 / 270$ without an aneuploid fetus.

Data analysis was performed with IBM SPSS Statistics 20.0 software (London, UK). Categorical variables were expressed as number and percentages. Distribution of data were assessed by KolmogorovSmirnov test. Parametric data is assessed by ANOVA test. Non-parametric data is evaluated by Kruskal-Wallis test. Data were expressed as means \pm standard deviations. A p-value $<0.05$ is considered significant.

\section{Results}

At the time of first trimester genetic screening test, demographic characteristics were shown in Table $\mathbf{1}$. Both groups were similar in terms of maternal age, gravidity, parity and CRL measurements at the time of screening except for body mass indexes (BMI). BMI of unilateral uterine artery notch group was found significantly lower than control group and bilateral notch group $(\mathrm{p}<0.001)$. No significant difference in body mass indexes was found between bilateral uterine artery notch group and control group. Fetal birth weight and gestational age at birth were found significantly lower at the notch group $(\mathrm{p}<0.001)$ (Figs. 1 and 2). B-hCG levels, nuchal translucency (NT) measurements were found similar between control, unilateral and bilateral uterine artery notch groups (Table 2). PAPP-A values were found significantly lower in unilateral uterine artery notch group in comparison with

Table 1. Demographic and clinical characteristics of the pregnancies.

\begin{tabular}{|c|c|c|c|c|}
\hline & & Groups & & \\
\hline & $\begin{array}{l}\text { Control } \\
\text { group }\end{array}$ & $\begin{array}{l}\text { Study group } 1 \\
\text { Unilateral notch }\end{array}$ & $\begin{array}{l}\text { Study group } 2 \\
\text { Bilateral notch }\end{array}$ & p-value \\
\hline Number of patients & 200 & 268 & 149 & \\
\hline Maternal age (years) & $32.00 \pm 3.38$ & $30.97 \pm 5.90$ & $32.33 \pm 3.86$ & 0.009 \\
\hline Gravidity & $\begin{array}{c}1.75 \pm 0.92 \\
1(1-4)\end{array}$ & $\begin{array}{l}1.82 \pm 1.0 \\
1(1-4)\end{array}$ & $\begin{array}{l}1.87 \pm 1.0 \\
2(1-4)\end{array}$ & 0.573 \\
\hline Parity & $\begin{array}{c}0.76 \pm 0.98 \\
0(0-3)\end{array}$ & $\begin{array}{c}0.92 \pm 1.07 \\
0(0-3)\end{array}$ & $\begin{array}{c}0.87 \pm 1.02 \\
1(0-3)\end{array}$ & 0.327 \\
\hline Body mass index $\left(\mathrm{kg} / \mathrm{m}^{2}\right)$ & $\begin{array}{c}25.27 \pm 3.46^{*} \\
23.54(20.48-33.34)\end{array}$ & $\begin{array}{c}24.45 \pm 3.35^{*, \dagger} \\
23.44(20.34-33.85)\end{array}$ & $\begin{array}{c}25.64 \pm 3.482^{\dagger} \\
25.20(20.12-32.20)\end{array}$ & 0.001 \\
\hline Maternal smoking $(n / \%)$ & $15(7.5 \%)$ & $22(8.20 \%)$ & $11(7.38 \%)$ & 0.122 \\
\hline Crown-rump length (mm) & $\begin{array}{c}60.94 \pm 7.12 \\
60.20(44.90-78.60)\end{array}$ & $\begin{array}{c}59.93 \pm 7.34 \\
59.65(45.10-80.40)\end{array}$ & $\begin{array}{c}60.40 \pm 6.11 \\
60.10(44.50-76.10)\end{array}$ & 0.428 \\
\hline Gestational age at birth (weeks) & $\begin{array}{c}38.5 \pm 1.433 \\
38.30(35.3-41.00)\end{array}$ & $\begin{array}{c}38.2 \pm 1.522^{\dagger} \\
38.30(31.5-40.00)\end{array}$ & $\begin{array}{c}37.05 \pm 2.06^{\dagger, \neq} \\
38.00(31.00-40.10)\end{array}$ & $<0.001$ \\
\hline Fetal birth weight (g) & $\begin{array}{c}3136.6 \pm 666.9^{\ddagger} \\
3060(1840-4850)\end{array}$ & $\begin{array}{c}3065.4 \pm 610.9^{\dagger} \\
3020(1840-4560)\end{array}$ & $\begin{array}{l}2749.6 \pm 603.86^{t, \neq} \\
2870(1070-3870)\end{array}$ & $<0.001$ \\
\hline
\end{tabular}

*According to post hoc analysis, there is a statistically significant difference between the control group and the unilateral group ( $p<0.001) .{ }^{\dagger}$ According to post hoc analysis, there is a statistically significant difference between the unilateral group and bilateral notch group ( $p<0.001)$. ${ }^{\ddagger}$ According to post hoc analysis, there is a statistically significant difference between the control group and bilateral notch group $(p<0.001)$. Values are compared by ANOVA and Kruskal-Wallis test and are given as means \pm standard deviations. $p<0.05$ is significant. 


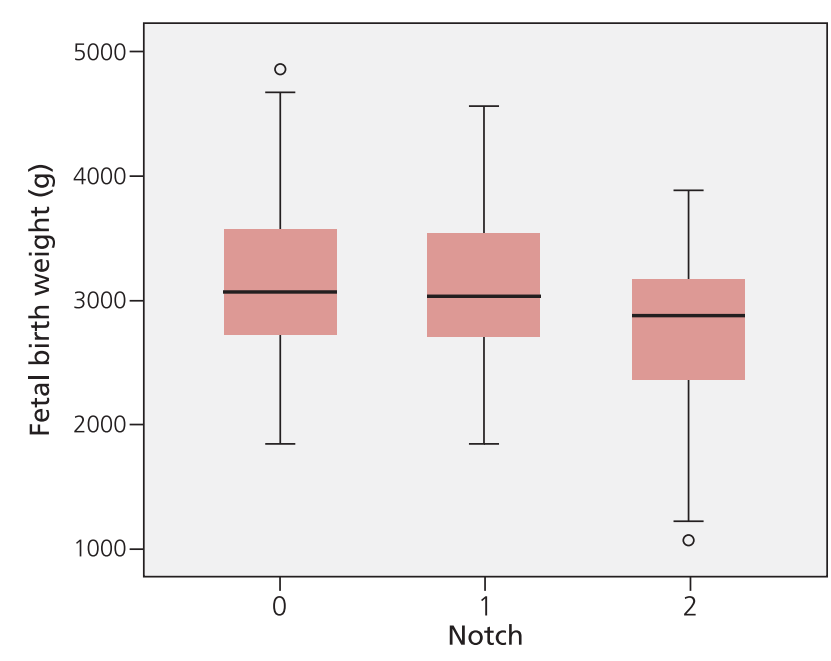

Fig. 1. Comparison of fetal birth weights $(\mathrm{g})$ in groups (0: Control group, 1: Study group 1/ unilateral notch group; 2: Study group 2/ bilateral notch group).

control group. In bilateral uterine artery notch group, PAPP-A values were significantly lower in comparison with both control group and unilateral uterine artery notch group $(\mathrm{p}<0.001)$ in terms of MoMs and mIU/L (Table 2; Figs. 3 and 4). Prevalence of false positive

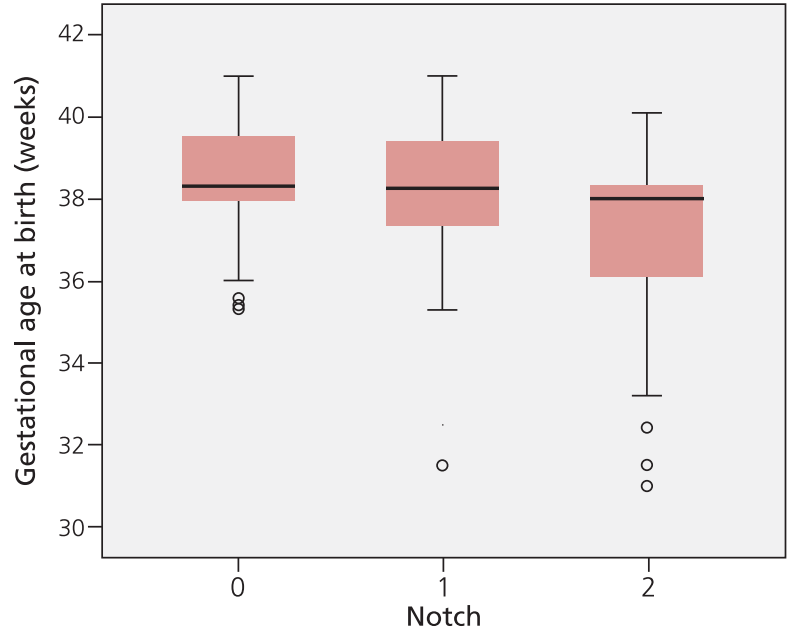

Fig. 2. Comparison of gestational ages at birth amongst groups (0: Control group, 1: Study group 1/ unilateral notch group; 2: Study group $2 /$ bilateral notch group).

first trimester aneuploidy screening test results were similar in controls and unilateral notch group. However, in bilateral uterine artery diastolic notch group false positivity in first trimester aneuploidy screening was significantly higher in comparison to uni-

Table 2. Comparison of first trimester screening test parameters of control group and notch groups.

\begin{tabular}{|c|c|c|c|c|}
\hline \multirow[b]{2}{*}{$\begin{array}{l}\text { 1st trimester screening } \\
\text { test parameters }\end{array}$} & \multicolumn{3}{|c|}{ Groups } & \multirow[b]{2}{*}{ p-value } \\
\hline & $\begin{array}{l}\text { Control } \\
\text { group } \\
(n=200)\end{array}$ & $\begin{array}{l}\text { Study group } 1 \\
\text { Unilateral notch } \\
\qquad(n=268)\end{array}$ & $\begin{array}{l}\text { Study group } 2 \\
\text { Bilateral notch } \\
\qquad(n=149)\end{array}$ & \\
\hline PAPP-A (mIU/L) & $\begin{array}{c}3839.7 \pm 2311.8^{*} \\
3336.5(848-13813)\end{array}$ & $\begin{array}{c}3838.9 \pm 1982.5^{\dagger} \\
3603.5(390.5-12543)\end{array}$ & $\begin{array}{l}2960.9 \pm 1720,7 *, \dagger \\
2684(681-9171)\end{array}$ & $<0.001$ \\
\hline PAPP-A MoM & $\begin{array}{c}1.28 \pm 0.70 * \\
1.19(0.34-4.44)\end{array}$ & $\begin{array}{c}1.30 \pm 0.63^{\dagger} \\
1.25(0.18-4.04)\end{array}$ & $\begin{array}{c}0.98 \pm 0.44^{*}, \dagger \\
0.89(0.25-2.35)\end{array}$ & $<0.001$ \\
\hline B-hCG (mIU/mL) & $\begin{array}{c}39.24 \pm 23.12 \\
32.07(7.23-122.00)\end{array}$ & $\begin{array}{c}40.83 \pm 24.86 \\
34.95(9.33-141.40)\end{array}$ & $\begin{array}{c}42.08 \pm 24.97 \\
34.26(10.14-152.00)\end{array}$ & 0.608 \\
\hline B-hCG (MoM) & $\begin{array}{c}1.21 \pm 0.70 \\
0.99(0.31-4.24)\end{array}$ & $\begin{array}{c}1.23 \pm 0.76 \\
1.01(0.32-4.94)\end{array}$ & $\begin{array}{c}1.28 \pm 0.74 \\
1.09(0.29-4.63)\end{array}$ & 0.698 \\
\hline $\mathrm{NT}(\mathrm{mm})$ & $\begin{array}{c}1.42 \pm 0.30 \\
1.40(0.81-2.32)\end{array}$ & $\begin{array}{c}1.41 \pm 0.34 \\
1.39(0.63-2.35)\end{array}$ & $\begin{array}{c}1.43 \pm 0.35 \\
1.41(0.84-2.47)\end{array}$ & 0.786 \\
\hline NT (MoM) & $\begin{array}{c}0.90 \pm 0.17 \\
0.89(0.48-1.43)\end{array}$ & $\begin{array}{c}0.92 \pm 0.22 \\
0.86(0.39-1.73)\end{array}$ & $\begin{array}{c}0.91 \pm 0.21 \\
0.89(0.53-1.48)\end{array}$ & 0.858 \\
\hline False positive test results, $\mathrm{n}(\%)$ & $21(10.5 \%)^{\ddagger}$ & $26(9.7 \%)^{\S}$ & $29(19.4 \%)^{\ddagger}, \S$ & 0.009 \\
\hline
\end{tabular}

${ }^{*}$ According to post hoc analyzes there is a statistically difference between control group and bilateral group $(p<0.001)$. ${ }^{\dagger}$ According to post hoc analyzes there is a statistically difference between unilateral group and bilateral notch group $(p<0.001)$. ${ }^{\ddagger}$ According to post hoc analyzes there is a statistically difference between control group and bilateral group $(p=0.009)$. $§$ According to post hoc analyzes there is a statistically difference between unilateral group and bilateral notch group ( $p=0.009)$. Values are compared by Kruskal-Wallis test and are given as means \pm standard deviations. p<0.05 is significant. B-hCG: beta human chorionic gonadotropin; MoM: multiples of median; NT: nuchal translucency; PAPPA: pregnancy associated plasma protein A. 


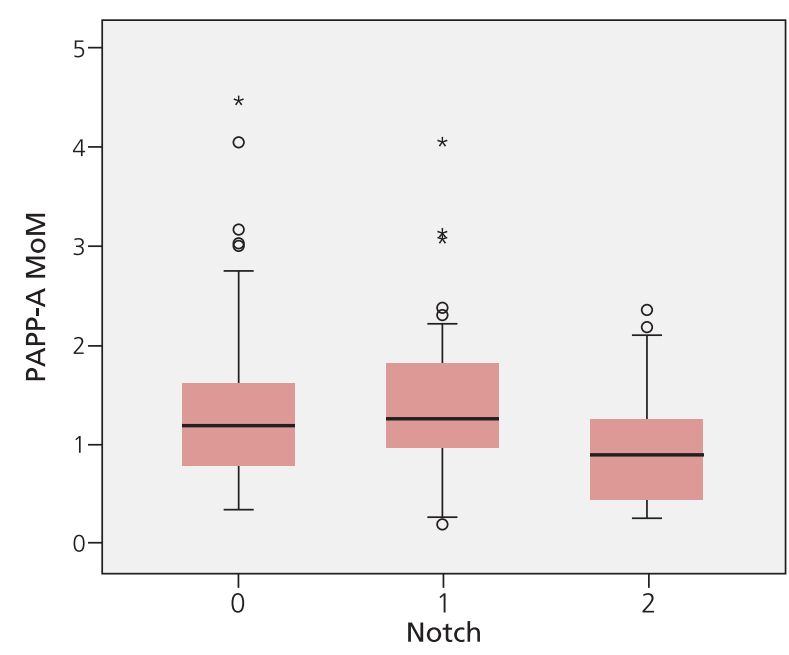

Fig. 3. Comparison of PAPP-A MoM values amongst groups (0: Control group, 1: Study group 1/ unilateral notch group; 2 : Study group 2/ bilateral notch group).

lateral notch group and controls $(\mathrm{p}=0.009$ and $\mathrm{p}=0.009$ respectively) (Table 2).

Gestational ages at birth and fetal birth weights were significantly lower in unilateral uterine artery notch group when compared to control group. In bilateral artery notch group, gestational ages at birth and fetal birth weights were significantly lower in comparison to both control group and unilateral artery notch group $(\mathrm{p}<0.001)$.

\section{Discussion}

In our study PAPP-A levels, PAPP-A MoMs, gestational ages at birth, fetal birth weights were found significantly lower in bilateral uterine artery diastolic notch group in comparison with both unilateral artery diastolic notch group and control group. These mentioned parameters were also found significantly lower in unilateral artery diastolic notch group comparing to control group. PAPP-A is secreted from syncytial trophoblasts, so similar to high uterine artery impedance, lower plasma PAPP-A levels are found in correlation with impaired placental function in several other studies. ${ }^{[5]}$ Our findings in terms of the association of uterine artery diastolic notch with some adverse pregnancy outcomes such as lower gestational age at birth and lower fetal birth weight correlates with the findings of some previous studies that indicate an association of

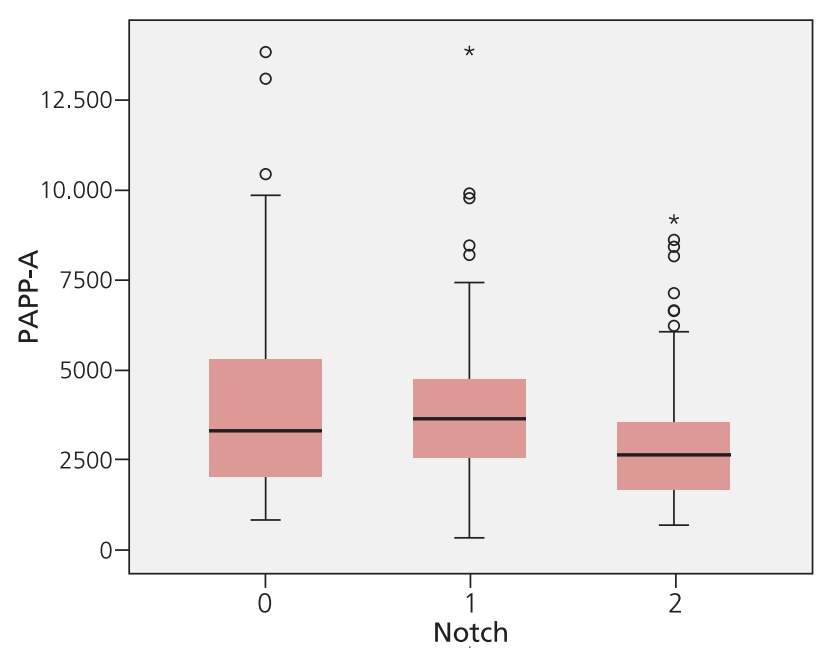

Fig. 4. Comparison of PAPP-A levels (mIU/L) amongst groups (0: Control group, 1: Study group 1/ unilateral notch group; 2 : Study group 2/ bilateral notch group).

these parameters. In these studies, similar to our findings, bilateral notching is associated with worse obstetric outcomes than unilateral notching. ${ }^{[12]}$

Although demographic characteristics of all groups were found similar, body mass index of unilateral uterine artery diastolic notch group was found significantly lower than other groups. Studies indicate an inverse correlation with serum PAPP-A levels and body mass index in pregnant women. ${ }^{[13]}$ Furthermore there was no significant difference between body mass indexes of bilateral uterine artery notch group and control group so this finding does not seem to confound the association between lower PAPP-A levels and presence of uterine artery diastolic notch.

In some other studies decreased UTPI values were shown to be associated with aneuploidies ${ }^{[8]}$ Furthermore lower UTPI values were proposed as a potential parameter that could help to identify aneuploidies in women with decreased plasma PAPP-A levels. ${ }^{[9]}$ Low PAPP-A levels could be attributed to impaired placental function in pregnancies with high uterine artery impedance as previously mentioned. ${ }^{[8]}$ On the other hand low PAPP-A levels are probably associated with some post translational alterations in aneuploid pregnancies such as impaired protein transport, decreased protein stability and changes in release mechanisms. ${ }^{[14]}$ Parallel to those studies, we found decreased PAPP-A levels and PAPP- 
A MoMs in uterine artery diastolic notch groups and that severity increases in bilateral uterine artery notch group. As expected, low PAPP-A levels might lead to increased rates of false positive first trimester aneuploidy screening tests, unnecessary invasive procedures and consequently higher rates of procedure associated complications. In our study, we observed that prevalence of false positive first trimester screening test was significantly higher in bilateral uterine artery diastolic notch group. However, this finding should be interpreted with caution due to small sample size of the study.

First trimester aneuploidy screening is a standard part of obstetric follow-up, nevertheless to this date first trimester uterine artery Doppler studies were not considered a part of routine obstetric care by most of the obstetricians. However, it has been shown that first trimester screening of preeclampsia with a combination of PAPP-A levels, placental growth factor levels, UTPI and maternal risk factors have a detection rate of $77 \%$ for preeclampsia that develops before 37 th gestational week. ${ }^{[15]}$ ASPRE study demonstrated that prophylactic administration of low-dose aspirin in these high risk patients could reduce the risk of preeclampsia up to $60 \% \cdot{ }^{[16]}$ Recently FIGO recommended screening of all pregnant women for preeclampsia with parameters including first trimester uterine artery Doppler indices. ${ }^{[7]}$ Adjusting risk estimations in first trimester aneuploidy screening with low PAPP-A levels in accordance with the presence of first trimester uterine artery diastolic notch or using non-invasive prenatal tests in such women could be considered.

In this study, we demonstrated the association between low maternal serum PAPP-A levels, high false positive first trimester aneuploidy screening test rate and uterine artery diastolic notches in first trimester of pregnancy. However, small sample size and retrospective design are main limitations of this study.

\section{Conclusion}

Although adjusting risk estimations of first trimester screening parameters in accordance with the presence of uterine artery diastolic notches is out of scope for our study due to some limitations such as design and small sample size, it may provide a useful guide for future studies that could include larger populations with the help of changing obstetrical practices.
Funding: This work did not receive any specific grant from funding agencies in the public, commercial, or not-for-profit sectors.

Compliance with Ethical Standards: The authors stated that the standards regarding research and publication ethics, the Personal Data Protection Law and the copyright regulations applicable to intellectual and artistic works are complied with and there is no conflict of interest.

\section{References}

1. Lin TM, Galbert SP, Kiefer D, Spellacy WN, Gall S. Characterization of four human pregnancy-associated plasma proteins. Am J Obstet Gynecol 1974;118:223-36. [PubMed] [CrossRef]

2. Conover CA. Key questions and answers about pregnancyassociated plasma protein-A. Trends Endocrinol Metab 2012; 23:242-9. [PubMed] [CrossRef]

3. Conover CA, Bale LK, Overgaard MT, Johnstone EW, Laursen UH, Füchtbauer E-M, et al. Metalloproteinase pregnancy-associated plasma protein A is a critical growth regulatory factor during fetal development. Development 2004;131: 1187-94. [PubMed] [CrossRef]

4. García-Castellanos R, Tallant C, Marrero A, Solà M, Baumann U, Gomis-Rüth FX. Substrate specificity of a metalloprotease of the pappalysin family revealed by an inhibitor and a product complex. Arch Biochem Biophys 2007;457:57-72. [PubMed] [CrossRef]

5. Patil M, Panchanadikar TM, Wagh G. Variation of papp-a level in the first trimester of pregnancy and its clinical outcome. J Obstet Gynaecol India 2014;64:116-9. [PubMed] [CrossRef]

6. Dugoff L, Hobbins JC, Malone FD, Porter TF, Luthy D, Comstock CH, et al. First-trimester maternal serum PAPP$\mathrm{A}$ and free-beta subunit human chorionic gonadotropin concentrations and nuchal translucency are associated with obstetric complications: a population-based screening study (the FASTER Trial). Am J Obstet Gynecol 2004;191:144651. [PubMed] [CrossRef]

7. Poon LC, Shennan A, Hyett JA, Kapur A, Hadar E, Divakar $\mathrm{H}$, et al. The International Federation of Gynecology and Obstetrics (FIGO) initiative on pre-eclampsia: a pragmatic guide for first-trimester screening and prevention [published correction appears in Int J Gynaecol Obstet 2019 Sep;146:390391]. Int J Gynaecol Obstet 2019;145 Suppl 1(Suppl 1):1-33. [PubMed] [CrossRef]

8. Prodan N, Wagner P, Sonek J, Hoopmann M, Mutz A, Brucker S, et al. First trimester uterine artery pulsatility index levels in euploid and aneuploid pregnancies. Arch Gynecol Obstet 2019;300:1559-64. [PubMed] [CrossRef]

9. Staboulidou I, Galindo A, Maiz N, Karagiannis G, Nicolaides KH. First-trimester uterine artery Doppler and serum pregnancy-associated plasma protein-a in preeclampsia and chromosomal defects. Fetal Diagn Ther 2009;25:336-9. [PubMed] [CrossRef]

10. Gestational hypertension and preeclampsia: ACOG Practice Bulletin, Number 222. Obstet Gynecol 2020;135:e237-e260. [PubMed] [CrossRef] 
11. O'Gorman N, Tampakoudis G, Wright A, Wright D, Nicolaides KH. Uterine artery pulsatility index at 12, 22, 32 and 36 weeks' gestation in screening for pre-eclampsia. Ultrasound Obstet Gynecol 2016;47:565-72. [PubMed] [CrossRef]

12. Yazıcıŏ̆lu F, Oran R, Özsoy B, Aygün M, Özyurt ON, Demirbaş $\mathrm{R}$, et al. The role of uterine artery Doppler and maternal serum d-dimer levels in prediction of preterm labor. Perinatal Journal 2007;15:99-107.

13. Varashree BS, Belle VS, Krishnananda Prabhu RV, Rao P. Influence of obesity on first trimester screening markers in singleton pregnant women enrolled at tertiary care hospital. Malaysian Journal of Biochemistry and Molecular Biology 2019;22:148-51.
14. Brizot ML, Hyett JA, Mckie AT, Bersinger NA, Farzaneh F, Nicolaides KH. Gene expression of human pregnancy-associated plasma protein-A in placenta from trisomic pregnancies. Placenta 1996;17:33-6. [PubMed] [CrossRef]

15. Rolnik DL, Wright D, Poon LCY, Syngelaki A, O'Gorman N, de Paco Matallana C, et al. ASPRE trial: performance of screening for preterm pre-eclampsia. [published correction appears in Ultrasound Obstet Gynecol 2017;50:807] Ultrasound Obstet Gynecol 2017;50:492-495. [PubMed] [CrossRef]

16. Rolnik DL, Wright D, Poon LC, O'Gorman N, Syngelaki A, de Paco Matallana C, et al. Aspirin versus placebo in pregnancies at high risk for preterm preeclampsia. N Engl J Med 2017; 377:613-22. [PubMed] [CrossRef]

This work is licensed under the Creative Commons Attribution-NonCommercial-NoDerivs 4.0 Unported (CC BY-NC-ND4.0) License. To view a copy of this license, visit http://creativecommons.org/licenses/by-nc-nd/4.0/ or send a letter to Creative Commons, PO Box 1866, Mountain View, CA 94042, USA.

Publisher's Note: The content of this publication does not necessarily reflect the views or policies of the publisher, nor does any mention of trade names, commercial products, or organizations imply endorsement by the publisher. Scientific and legal responsibilities of published manuscript belong to their author(s). The publisher remains neutral with regard to jurisdictional claims in published maps and institutional affiliations. 